\title{
Socio-political-environmental perceptions of participants in the public hearings of the Brazilian Representative House on Environment
}

\author{
Antonio Teixeira de Barros
}

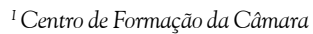
dos Deputados (CEFOR), Brasília, DF, Brasil.

\begin{abstract}
The article analyzes the perceptions of the citizens who participated in the public hearings promoted by the Committee on Environment and Sustainable Development (CMADS) of the Chamber of Deputies during the year 2018. The methodology consisted in the use of a questionnaire with open and closed questions applied to a sample of $71.22 \%$ of the public that was present at these events. For the study of perceptions, open questions are particularly relevant, since they consist of arguments, analyzes and justifications presented by citizens, based on the experience of participating. The conclusions show that a diversity of citizens' perceptions of the CMADS agenda, the topics under debate and the participation of technicians and representatives of entities from the environmental field. On the other hand, there are critical opinions in relation to the performance of parliamentarians, representatives of government agencies and the dynamics of debates.
\end{abstract}

Keywords: Environmental perceptions; public hearings; Commission for the Environment and Sustainable Development; Chamber of Deputies

São Paulo. Vol. 24, 2021

Original Article

DOI: http://dx.doi.org/10.1590/1809-4422asoc20190083r2vu2021L1AO 


\section{Introduction}

The study of social perceptions is widely used in the social sciences, anchored in the analytical principle called double hermeneutics (GIDDENS, 2009, p.335), that is, the analyst of social perceptions has as an object of empirical investigation phenomena "already constituted as significant for the investigated actors", although not always discursively formulated. It is important to emphasize, therefore, that the final product of analyzes of this nature results from a "double process of translation and interpretation that is involved in research operations and relations and in elucidating the cognitive capacity of social actors", with the purpose of understanding their discursive opinions and justifications (BARROS, 2015a, p.341).

Thus, the research work consists of getting to know what the actors already know about such phenomena, since social research is mediated by the informants' practical and discursive awareness. Practical awareness consists of everything that agents tacitly know about how to conduct themselves in the contexts of social life without, however, necessarily being able to express it discursively; it consists of knowing the rules and tactics by which everyday life is constituted and reconstituted in space and time. The mission of social research therefore involves the discursive explanation of aspects of motivation, cognition and conduct of agents who operate at the level of practical awareness, as well as the identification of unknown conditions and the unintended effects of these conducts, limiting factors the agents' cognoscitiveness (GIDDENS, 2009).

The literature on the study of social perceptions emphasizes, in general terms, that it is a methodological way to understand what citizens think about certain social and political problems (CONOVER, 1984; COVEYOU, 1984; EVELAND, 2013. On the other hand On the other hand, such studies refer to perspectives and not measures, understanding, therefore, that there are no empirical ways of directly measuring such perceptions, which make them susceptible to bias and controversy, including on the part of researchers (FERNANDEZ, 2008 ).

They are, therefore, indirect measures, which reveal traces of the cultural elements that permeate such perceptions (BONNEMAINS, 2016). However, they are useful for capturing subjective assessments of citizens, agents and observers of social practices. Therefore, they are actors whose perceptions are expressive for the analytical study and the hermeneutical understanding of social and political problems, in qualitative terms. Thus, when analyzing social perceptions on a given theme, what is studied is how practices have become symbolic and materially hegemonic, self-evident, binding.

Rancière (2005) associates the notion of social perception with the sharing of the sensitive, referring to the sharing of spaces, temporalities, activities, perspectives, feelings and emotions. Mairin, Torres and Comar (2003) present two interrelated dimensions of the notion of perception, one being materialistic and the other symbolic or spiritual. The first refers to the apprehension of the world by the senses, while the second includes the imaginary, subjective reflection, ideologies, beliefs, values, prejudices and other immaterial elements. The post-materialist values approach considers mainly the individual perceptions, whose assumption is the adoption of individual practices and habits, like 
conscious consumption. It is the behaviors of citizens that are brought to the forefront (DUNLAP; MERTIG, 1997).

For Lahire (2002), individual perceptions result from socialization, that is, from the role of society's logic in individual personalities. After all, individual acts, perceptions and actions are also social, since any individual, when thinking, doing or interpreting, carries with him the senses and values of his family, his group, his class, his time, in short of society where you live.

Based on the understanding that environmental perceptions constitute a type of social perception, the article aims to analyze the perceptions of the public that attended public hearings promoted by the Environment and Sustainable Development Commission of the Chamber of Deputies (CMADS) in 2018. The problem to be investigated consists of the following questions that complement each other: (a) what is the profile of this audience? (b) what are your perceptions of these public hearings? (c) how are these events evaluated by the public? (d) what criticisms are made?

The main justification for this type of study is the argument that public hearings are an instrument for the participation of civil society in legislative debates (BARROS; MONTEIRO; SANTOS, 2018). Therefore, citizens' assessment and perception of such events must be taken into account in a democratic society that has parliament as its official representative.

The study is based on data from a questionnaire with open and closed questions applied to citizens who participated in the aforementioned public hearings throughout 2018 (Appendix) $^{1} .552$ questionnaires were applied, which corresponds to a sample of $71.22 \%$ of the public that was present at these events throughout that year. For the collection of data, we count on the collaboration of the CMADS logistics team, which distributed the questionnaire to the participants at the end of the 32 public hearings held throughout 2018. The option for the end of the session is justified by the evaluative nature of the questions, which would be inappropriate before the discussions.

For the study of perceptions, open questions assume special relevance, since they consist of arguments, analyzes and justifications presented by citizens, based on the experience of participating in the aforementioned public hearings. For the analysis of open questions, we used the technique of content analysis, more specifically the thematic analysis, understood as a semantic grouping of responses, according to the theme addressed by the informants (BARDIN, 2005). The answers to closed questions are presented throughout the text in the form of descriptive statistics.

Before analyzing the data, we present a brief bibliographic review on the concept of environmental perception, in its various theoretical dimensions.

\section{Environmental perception}

Marin (2008), Carvalho and Steil (2013) record that the origin of studies on

1 - It should be noted that the questionnaire is extensive and it was not possible to include all the questions in the analysis presented here. 
perception lies in psychology, a discipline that would increase their contribution to the emergence of environmental psychology (TERENCE, 1977; GIBSON, 1979) from 1960 onwards. Studies on perception they started to count on the contributions of humanistic geography (TUAN, 1972; HELPH, 1976; HOLZER, 1996), in addition to the contributions of phenomenology, with the analysis of Merleau Ponty (1999) on phenomenology of perception.

In psychology, perception is understood as the "organization of information transmitted by sensations that allow to know reality". The perception "is due to the properties of sensory stimulation that, in turn, derive from the properties of the environment and its objects (MESQUITA; DUARTE, 1996, without pagination). Environmental psychology prioritizes the study of perceptions based on the interaction of individuals with the environment, while humanistic geography emphasizes the role of cultural values in shaping perceptions about landscape and space. Phenomenology, in turn, considers the relationships between body, perception and knowledge (NÓBREGA, 2008). It is appropriate to reinforce the perspective of environmental psychology here. As Carvalho and Steil (2013, p.62) point out:

the environmental perception as understood by environmental psychology moves from the perception of object to horizons of a large scale, size and temporality, associated with the molar character of the ambiences that surround the existential space. Likewise, since the perceived environments include the subject, environmental perception tends to dissolve the subject-object dichotomy, thus overcoming situationist and interactionist theories in psychology that, in one way or another, are fixed in unidirectional analyzes. of person x environment relations.

Environmental perceptions are also understood as the way in which each individual evaluates issues and problems related to the environment, either about the surrounding environment or on issues related to the environmental agenda in a broader way, including the action of social, political and governmental actors (FERNÁNDEZ, 2008). Thus, the study of environmental perceptions can contribute to improving environmental management policies, increasing their legitimacy, by adopting perspectives that contemplate the collective interest. In addition, the empirical study of environmental representations is useful for understanding the justification records of individuals (MAILLEFERT; MERLIN-BROGNIART, 2016).

From the perspective of social sciences, as well as social perceptions, environmental perceptions are anchored in individuals' cultural substrates, which are socially shared in specific contexts or in relation to certain themes. These cultural supports comprise people's views and representations about nature and the relationship between human beings and natural resources. This perspective assumes that culture is a source of meanings for social and environmental problems (MILTON, 2002). For Mary Douglas (1978; 2013), individual perceptions are built from a given cultural order, with their cultural bias, 
which shape the senses on the questions posed to citizens, whose reference is symbolic systems, which are socially shared, legitimized and redefined according to the changes and socio-cultural dynamics of each context.

In this view, perceptions come from both the direct experience of individuals and social interaction and exposure to media content, since the media have become highly expressive cultural agents (BARROS, 2015b). In this order of ideas, it is worth noting that the very notion of the environment is socially and culturally constructed (DURAND, 2008), as well as the other notions associated with ecological issues, including the individual and their personal representations (ALLOUCHE; NICOLAS, 2015). Such a view also contemplates the cognitive dimension, that is, the way in which individuals perceive problems and issues related to the environment (BONNEMAINS, 2016).

Marques (2007, p.144) points out three types of mechanisms that interfere in social perceptions: (a) environmental. (b) cognitive; (c) relational. In the first case, contextual factors stand out, based on characteristics and aspects related to the surrounding environment. In the second, there are "the actions that relate to the perceptions and mental states of individuals and social groups". Relational mechanisms, in turn, "mobilize the relationships between individuals, groups and organizations, as well as the general patterns formed by such sets of relationships, forming social networks" (MARQUES, 2007, p.144).

Despite recognizing the role of the three mechanisms mentioned, the author stresses the relevance of relational aspects in the formation of social perceptions, since the strength of relational mechanisms is inherent to social life, which is organized based on the constitution of relational networks at various levels. , scope and durability. A factor highlighted in this process is the daily conversations and interactions, which stimulate the reinforcement or rejection of certain perceptions that circulate between the groups (EVELAND JR; HUTCHENS, 2013). Conover (1984) reiterates that, in this relational perspective, the influences of groups on individual perceptions are important, as group identifications play an important role in defining the views and perceptions that people formulate about the environment. Individuals who identify with different groups focus on different things and evaluate political issues from different perspectives.

Environmental perceptions are complex, depending on the theme and the audience. There are relatively consensual issues among some social segments, such as global warming and pollution, but there are also themes in which perceptions are very varied or even wrong, depending on the level of technical knowledge necessary to understand the problem under debate (DUNLAP , 1998). The perceptions are affected by the personal values, spiritual beliefs and world views of citizens (SLIMAK; DIETZ, 2006), in addition to their personal experiences (MILTON, 2002). Other studies also consider the impacts of the visibility of environmental problems and the intensity of the mobilization of environmental movements (GOULD, 1993).

For Yearley (2014), environmental perceptions, in global terms, were largely influenced by the green wave that started in the 1990s. This wave, whose landmark was Rio 92, contributed to spread environmental awareness, from a perspective that defending the ecological agenda is a progressive and elegant attitude, leading this agenda to be 
adopted, even by politicians, businessmen and advertising agencies.

In the study of socio-environmental perceptions in the field of social sciences, some concepts stand out, such as: social representation and environmental perspective. The concept of social representation, understood as "a specific form of knowledge, anchored in common sense, but which expresses a form of social thought" (JODELET, 2008, p.474). In this approach, the focus is on social processes "in around a particular aspect, which may be the environment, natural phenomena and other aspects" (AGUILAR; MERÇON; RIVERA, 2018, p.97). The term perception focuses on a specific object that may be the natural environment or In addition to referring to individuals looking at environmental issues, it is about apprehending collective representations, shared from common social perspectives.

For Moscovici (2003), social representations serve as a substrate for common knowledge, one that is part of everyday life, constituted by common sense. It is a type of knowledge socially produced and disseminated, whose main function is to assist individuals in the daily symbolic operations of interpreting, thinking and acting on reality. Moscovici (2003) called this type of knowledge consensual universes of thought, constituted by the individuals themselves in their belonging groups. It is worth noting how this approach attributes agency power to the common individual, as an actor in social life, capable of producing and disseminating knowledge about his daily life, based on the relationship with his peers and peers.

In this debate, it is important to emphasize the relevance of the concept of environmental perspectives (DURAND, 2008), which comprises the process of (re) structuring individual perceptions based on social experiences and their consequent multiplicity of interpretations. Thus, the notion of environmental perspective incorporates possible influences from socio-cultural cleavages, such as education, income level, sex, ethnicity, gender and place of residence. In short, the outlook is conditioned by socioeconomic status, cultural capital and social capital.

The concept of environmental perspective comes close to the notion of social perspective, which is understood as the structural social positions that produce particular, situated and contextualized experiences. This is because social perspective concerns the "point of view that members of a group have about social processes because of their position in them" (YOUNG, 2000, p.137). The concept of social perspective expresses a socially situated position, a way of understanding reality from a specific social place. Thus, social perceptions are conditioned by the person's position in society, depending on their class, income, gender, color or ethnicity.

\section{Data analysis}

In 2018, CMDAS held 32 public hearings, with an average of 25 participants per event, totaling 775 people (BRASIL, 2017). Of this total, we obtained 552 subjects who were willing to answer the questionnaire, which corresponds to a sample of $71.22 \%$. It should be noted that we were careful to prevent the same person from answering the questionnaire more than once. 
The data shown in Table 1 reveal, in reality, the public profile of the audiences promoted by CMADS, with a predominance of men, aged 31 to 50 years, with higher education, family income in the two highest scales, linked to entities environmental, with a predominant party bond in the sympathizing category. Also noteworthy is the fact that $78.80 \%$ work in the environmental area, especially in the public sector, residing mainly in the Federal District.

The male majority draws attention, a fact that is almost always highlighted when it comes to the profile of citizens who participate in public life and in the arenas of political debates. A study by Barros, Monteiro and Santos (2018) shows similar percentages in relation to participation in interactive hearings promoted by the Chamber of Deputies, with $67.30 \%$ men and $32.70 \%$ women. It is a cultural and political heritage, resulting from a differentiated process of political socialization of women, which tends to restrict their performance in the private sphere, while producing impediments and obstacles when it comes to participation in the public sphere (BIROLI , 2016). It is worth noting a counterpoint registered in the literature that environmentalism has an expressive female militancy (BOY; BRUCE; DELGADO, 2002). Although militancy is a different field from the theme investigated here, the predominance of men in the participation in public hearings of CMADS is highlighted.

Table 1 - Profile of the informants

\begin{tabular}{|l|c|c|}
\hline SEX & Amount & $\%$ \\
\hline Male & 336 & 60,87 \\
\hline Female & 216 & 39,13 \\
\hline Subtotal & 552 & 100 \\
\hline AGE RANGE & Amount & $\%$ \\
\hline Up to 20 anos & 10 & 1,8 \\
\hline 21 a 30 anos & 90 & 16,3 \\
\hline 31 a 40 anos & 223 & 40,4 \\
\hline 41 a 50 anos & 149 & 27 \\
\hline 51 a 60 anos & 64 & 11,6 \\
\hline Over 60 anos & 16 & 2,9 \\
\hline Subtotal & 552 & 100 \\
\hline SCHOLLING & Amount & $\%$ \\
\hline Elementary Scholl & 2 & 0,36 \\
\hline High School & 92 & 16,67 \\
\hline Sighter School & 344 & 62,32 \\
\hline Posgraduated Studies & 114 & 20,65 \\
\hline Subtotal & 552 & 100 \\
\hline
\end{tabular}




\begin{tabular}{|c|c|c|}
\hline FAMILY MENSAL INCOMING & Amount & $\%$ \\
\hline Up to 3 minimum wages & 1 & 0,18 \\
\hline 3 a 5 minimum wages & 25 & 4,53 \\
\hline 6 a 10 minimum wages & 96 & 17,39 \\
\hline 11 a 15 minimum wages & 176 & 31,88 \\
\hline Above 15 minimum wages & 254 & 46,01 \\
\hline Subtotal & 552 & 100 \\
\hline $\begin{array}{l}\text { ASSOCIETED WITH ENVIRON- } \\
\text { MENTAL ENTITY }\end{array}$ & Amount & $\%$ \\
\hline Yes & 283 & 51,3 \\
\hline No & 269 & 48,7 \\
\hline Subtotal & 552 & 100 \\
\hline POLITICAL PARTY AFFILIATION & Amount & $\%$ \\
\hline Sympathizer & 234 & 42,4 \\
\hline Not affiliated & 183 & 33,2 \\
\hline Affiliated & 135 & 24,4 \\
\hline Subtotal & 552 & 100 \\
\hline $\begin{array}{l}\text { WORKS IN THE ENVIRONMEN- } \\
\text { TAL AREA }\end{array}$ & Amount & $\%$ \\
\hline Yes & 435 & 78,8 \\
\hline No & 117 & 21,2 \\
\hline Subtotal & 552 & 100 \\
\hline $\begin{array}{l}\text { PROFESSIONAL ACTIVITY SEC- } \\
\text { TOR }\end{array}$ & Amount & $\%$ \\
\hline Public Setor & 350 & 63,41 \\
\hline Third Sector & 183 & 33,15 \\
\hline Private Sector & 19 & 3,44 \\
\hline Subtotal & 552 & 100 \\
\hline PROVINCE OF RESIDENCE & Amount & $\%$ \\
\hline Distrito Federal & 423 & 76,63 \\
\hline Goiás & 60 & 10,87 \\
\hline Mato Grosso & 33 & 5,98 \\
\hline Minas Gerais & 14 & 2,54 \\
\hline Mato Grosso do Sul & 12 & 2,17 \\
\hline Others & 10 & 3,98 \\
\hline Subtotal & 552 & 100 \\
\hline
\end{tabular}

Source: Prepared by the author. 
Despite the party affiliation being $24.4 \%$, the high percentage of informants who declare themselves to be sympathetic $(42.4 \%)$ is noteworthy. Added to these two categories, we have $66.8 \%$. Sympathy is considered in the literature as a form of party identification, as it clearly expresses a political preference, although there is no formal affiliation link. In reality, the two categories are formed by supporters, and the affiliates decide to formalize their party sympathy (CABRAL, 1995).

Among the members, there is a predominance of ecologically oriented parties, the first being PV $(46.67 \%)$ and Rede $(22.96 \%)^{2}$, considered to be supporters of systemic political ecology, that is, they present a moderate ecological profile, unlike radical environmentalist or eco-socialist parties (BARROS, 2018). Despite internal differences, PV and Rede converge in the defense of an integrated and systemic vision of sustainability, bringing together several dimensions such as economic, political, social, cultural, spatial and environmental. The debates promoted by CMADS seem to interest the affiliates of these legends, allied to other factors, such as professional performance and proximity to environmental protection entities.

The others are affiliated with parties such as PSOL (8.89\%), PSB (8.15\%), PDT (3.70\%), PT (3.70\%), PCdoB (2.96\%), PCO (2 , 22\%) and PEN (0.74\%). It should also be noted that the informants' affiliation is practically on the left and center-left spectrum, bringing together parties that have come to prioritize sustainability in their programs in the recent context, gathered under the nickname of the green left (BARROS, 2018). It is a set of subtitles that, even without a clear ecological orientation - unlike PV and Rede -, adhered to the environmental agenda in a more ostensible way, aligned with the criticism of capitalism and the resumption of eco-socialist ideas, such as the PDT, PSOL . PSB, PCdoB, PT and PCO. Although there are differences in the emphases attributed to environmental issues in their programs, these associations share the ideal of the approximation between socialism and ecological sustainability, whose exponent was the French Socialist Party (SAINTENY, 1994; DUVERGER, 2011).

\section{Audience assessment}

Table 2 summarizes all the questions that express the public's evaluation. ${ }^{3}$ The set of perceptions that concern the performance of deputies in the hearings stands out, with a predominance of regular assessment (63.2\%). The performance of guests and exhibitors (column 3) and representatives of environmental entities are the items with the highest percentages from the perspective of public assessment.

Open responses help to deepen such perceptions. As for the assessment of the hearings, the arguments that express a favorable assessment are as follows:

2. These percentages refer to the universe of $24.4 \%$ of respondents who claimed to be affiliated with any party.

3. Each column corresponds to a question in the questionnaire, emphasizing that not all questions were explored due to lack of space. In addition, some questions were reordered in the table in order to make the analysis more systematic. 
- Invite high quality technicians to the debate.

- They bring up relevant issues.

- Quality of debates and importance of topics.

- Little audience, but good debaters.

Critics point out that:

- There are many delays, which affects the amount of time that should be devoted to the debate.

- They are not very effective; nothing new is done.

- Little popular participation and low disclosure.

- They favor the government side; the voice of environmentalists is in the background, just for the record.

Table 2 - Evaluation of participants in public hearings

\begin{tabular}{lccccccc}
\hline Evaluation & $\begin{array}{c}\text { How do you } \\
\text { assess audi- } \\
\text { ences? }\end{array}$ & $\begin{array}{c}\text { How do you } \\
\text { evaluate the } \\
\text { quality of the } \\
\text { debates? }\end{array}$ & $\begin{array}{c}\text { How do you } \\
\text { evaluate the } \\
\text { performance } \\
\text { of deputies? }\end{array}$ & $\begin{array}{c}\text { How do you } \\
\text { evaluate the } \\
\text { performance of } \\
\text { the Governmental } \\
\text { representatives? }\end{array}$ & $\begin{array}{c}\text { How do you } \\
\text { evaluate the } \\
\text { performance of } \\
\text { environmental- } \\
\text { ists? }\end{array}$ & $\begin{array}{c}\text { How do you } \\
\text { evaluate the } \\
\text { performance of the } \\
\text { in the environ- } \\
\text { mental area? }\end{array}$ & $\begin{array}{c}\text { How do you evaluate } \\
\text { Brazils performance } \\
\text { in the environmental } \\
\text { sector? }\end{array}$ \\
\hline Excelente & $6,5 \%$ & $21 \%$ & $3,3 \%$ & $29,3 \%$ & $31,9 \%$ & $0,18 \%$ & $0,36 \%$ \\
\hline Boa & $76,5 \%$ & $61,8 \%$ & $19,4 \%$ & $52,5 \%$ & $48,6 \%$ & $1,27 \%$ & $10,69 \%$ \\
\hline Regular & $15,9 \%$ & $0,1 \%$ & $63,2 \%$ & $17 \%$ & $17,8 \%$ & $3,62 \%$ & $50,18 \%$ \\
\hline Ruim & $0,7 \%$ & $13,9 \%$ & $11,6 \%$ & $0,9 \%$ & $1,6 \%$ & $7,97 \%$ & $15,04 \%$ \\
\hline Péssima & $0,4 \%$ & $3,2 \%$ & $2,5 \%$ & $0,3 \%$ & $0,1 \%$ & $86,96 \%$ & $23,73 \%$ \\
\hline TOTAL & $100 \%$ & $100 \%$ & $100 \%$ & $100 \%$ & $100 \%$ & $100,00 \%$ & $100 \%$ \\
\hline
\end{tabular}

Fonte: Prepared by the author, 2018.

Some aspects call attention to the public's evaluation, such as the emphasis on the topics discussed and the technical qualification of the guests, which leads us to deduce that CMADS audiences are recognized by this audience as a qualified forum for environmental debate. As Lima, Araújo and Seraphim (2017, p.261) point out, the Brazilian legislative branch has undergone an opening process in recent years, "transforming itself into a political space that has been increasingly occupied by multiple interests". The lack of mention of the performance of the deputies stands out, whose performance is not well evaluated by the citizens consulted.

From the perspective of criticism, however, some informants consider that the hearings "are not very effective", because "nothing new is done", in a discursive framework that conditions the effectiveness of a political debate to some type of action resulting from it. Others consider the CMADS hearings to be a privileged space for the rhetorical legiti- 
mation of representatives of the Executive Branch. Low social participation, deficiencies in disclosure and delays in the start of debates appear as aspects criticized by the public.

Regarding parliamentary performance, citizens presented many criticisms, such as:

- The few who attend are not effective defenders of ecological causes.

- There is little interest from deputies.

- They should be more present, since the information is addressed to them.

- Demonstrate little affinity and knowledge about topics

- They are very uninformed.

It should be noted that there was no expression of praise about the performance of the deputies, who are perceived by the informants as "disinterested", "uninformed" and "without commitment to ecological causes". The judgment of citizens must be considered in the light of the composition of the CMADS in the period in which the questionnaire was applied. Of the 18 members of the commission, there was only one deputy from the Sustainability Network and one from the PV. All the others were linked to parties with no history of alignment with the environmental agenda, such as PP, PR, PRB, SD and PPS. Of the 18 members, parliamentarians with no ties to ecologically oriented social movements predominated. It is certainly for these reasons that the public assessment is presented in the way mentioned above.

Regarding the performance of government representatives, the informants argue that:

- Lack of objectivity and capacity for synthesis.

- Guests from government sectors are fallacious and have little technical knowledge.

- Those who speak for the Government just want to convince that the measures of the state are adequate, without opening for a more in-depth and critical debate.

As for the guests from the government sectors, the criticisms stand out, with emphasis on the rhetorical strategies to justify the speeches and official measures. Although the CMADS hearings are a legitimate forum for the expression of official representatives, the strategic use of this space is questioned by the public. Certainly this perspective is due to the predominance of rhetorical resources by these guests to present the environmental discourse as something consensual, institutionalizing a uniform discourse on ecological issues (BARROS, 2017; 2018).

According to Carvalho (1990, p.237), the official environmental discourse regulates, sets goals and produces ecological facts, based on merely rhetorical public justifications. Thus, "this speech names a certain development model as good and this is its measure for improvement and well-being. It calls for the preservation of nature, committed in advance 
to the rules of industrial capitalism and consumption "(CARVALHO, 1990, p.237). For the author, in the name of concepts with a strategic generality, the State affirms and reaffirms its institutionalized consensual speech, which establishes true effects and "produces the ecological fact from its point of view" (CARVALHO, 1990, p.235). This explains the nature of the official discourse, more precisely its persuasive and simplifying character, which tries to impose on society a "domesticated" view of environmental problems (BARROS, 2017).

When reporting to the actions of representatives of environmental entities, citizens explain that:

- They speak well, know the law and are experts on what they talk about.

- They are the ones who form an opinion in the environmental area.

- They do their job well, especially in the debates.

- The speech space is very short, which prevents a better performance.

In contrast, when assessing the performance of representatives of environmental entities, respondents present the short time for the exposure of these actors as their only caveat. Two aspects must be highlighted here. The first is that the legitimacy of these representatives' statements to the audience seems to be supported by the fact that $51.3 \%$ of the respondents to the questionnaire are linked to ecological entities.

Logically, there are $48.7 \%$ that belong to none of these entities, which are also manifested in a critical manner in relation to exhibitors representing environmental entities, leading us to assume that this second segment also evaluates discursive performance in a favorable way of these actors, in terms of contribution to the debate.

The second aspect is related to the recognized discursive competence of environmental entities, a phenomenon already recorded in the literature, as a result of the need for these institutions to conquer space in the media and in other arenas of public debate. Pereira Rosa (2006) states that the success of non-governmental environmental organizations in the field of contemporary environmental rhetoric is justified by a change of position and paradigm: the entities are no longer just promoters of protests and demonstrations to become references in diagnostics specialized, capable of presenting reliable technical analysis on the topics under discussion by the governmental agenda and the scientific community.

Thus, when they cease to be identified as having symbolic capital based merely on activism and environmental engagement, these organizations have become specialized entities, expert sources of high credibility. In addition, the author analyzes how these entities shaped their strategies to format their messages in order to attract the attention of the media and the public interested in the topic.

According to Barros (2015) this results from a broader process that produced changes in the environmentalist ethos and in the reformulation of its collective action repertoires. Despite the plurality, the diversity of the agenda and the discursive aspects of these entities (NUNES; PERES; SILVA, 2017), the perception of the informants tends to be uniform 
regarding the evaluation of the performance of the representatives of these entities in the CMADS hearings, which leads us to to deduce that all forms of discourse and action are considered valid by the citizens consulted.

The debates are well evaluated by the audience participants. Adding the excellent and good ratings, we have $82.80 \%$. Among the justifications for this result are:

- Bring relevant data and information.

- They present various angles and facets on the topics under discussion.

- Despite the weak performance of the deputies, the debates are of a high level.

- The arguments of representatives of environmental organizations qualify the debate.

As can be seen, the quality of the debates is attributed to external guests, especially representatives of environmental entities. The participation of parliamentarians is again criticized. Among the criticisms pointed out are:

- They're superficial.

- They are very polarized.

- Audience participation is lacking.

- They're not very democratic.

The prevailing perception is that Brazil has a regular performance in relation to environmental policies, in the recent context. Among the arguments presented by the public are:

- The advance of the ruralist parliamentary group has more and more strength to boycott environmental laws.

- The environmental agenda is no longer a priority for the Government and the Legislature.

- There seems to be an unspoken pact between Government and Congress to prevent the advance of environmental policies.

- Impunity, amnesty for environmental crimes and forgiveness of millionaire fines stimulate devastation.

- The agribusiness lobby is predominant in the country.

- Environmental movements have cooled their struggles.

Regarding the advance of the so-called ruralist parliamentary group, the perception of the informants finds support in the statistical data compiled by the Congress in Focus in 2016. According to the survey, 207 deputies are members of the Parliamentary 
Front in Defense of Agriculture, which corresponds to 40.35\% of the 513 deputies. Even the Parliamentary Environmentalist Front has more than 70\% of its members aligned with the interests of agribusiness, confirming the trend already registered in the anti-ecologism literature of the National Congress (ACCIOLY; SÁNCHEZ, 2012).

The performance of the National Congress has a 95\% disapproval from the informants, adding the alternatives "bad" and "terrible". Such performance is justified discursively by the following arguments:

- There is a monopoly of ruralist parliamentary group;

- It does not exercise its power of environmental inspection to the satisfaction;

- The New Forest Code was a setback;

- Congress does not have environmental policies as a priority.

Among the topics considered most relevant in the perception of the citizens consulted, the following stand out: climate change (22.45\%), combating deforestation $(18.68 \%)$, environmental education $(12.38 \%)$, combating environmental crimes (10, $64 \%)$; protection of forests and forests $(8.47 \%)$; combating fires $(5.72 \%)$; animal protection $(5.50 \%)$, protection of water sources and water resources $(5.14 \%)$, combating urban pollution (3.91\%) and combating environmental disasters (3.33\%).

The first theme is justified by the fact that it has become the main one in terms of visibility in recent years (BARROS, 2015), after the dissemination of data and scientific studies by the Intergovernmental Panel on Climate Change, an organization linked to the United Nations Program for the Environment (UNEP), as supported by the World Meteorological Organization (WMO). The perspective power of such initiatives contributed to raise the politicization of the environmental debate on a global scale, with emphasis on the level of public attention focused on the effects and consequences of climate change, which contributed to intensify its political relevance (RYAN, 2017).

The problem of deforestation is considered the Achilles heel of Brazil, with regard to the inefficiency of policies to contain the illegal exploitation of forest resources and forests. There are a number of factors that come together in this process and the radius of the so-called deforestation arc increases every year, especially in the Amazon and the Cerrado (DOMINGUES; BERMANN, 2012). These factors include: (a) the advance of agricultural frontiers; (b) deforestation for planting pasture; (c) fires; (d) illegal logging; (e) clandestine mining activity in forest areas. Despite the various factors mentioned, "medium and large farms are responsible for about 70\% of deforestation activities" (FEARNSIDE, 2005, p.113).

As the author points out, the removal of vegetation facilitates the spread of fires, with impacts such as loss of biodiversity and reduced rainfall, which contributes to global warming. As this is an audience familiar with the debate on environmental issues, these aspects certainly had a bearing on the respondents' responses.

The emphasis on environmental education is also directly related to the profile of 
the audience of the audiences, who understand well the role of education in the renewal of mentalities and habits. The generational component is also noteworthy, since it is a public with a predominantly young profile, since $58.5 \%$ of the informants are in the age range of 18 to 40 years (Table 1 ).

Gadotti (2008) attributes the increased interest of young people to sustainability as a contribution of the Decade of education for sustainable development (2005-2014), an initiative of the United Nations. For the author, education represents a relevant contact of young people with the culture of sustainability, in order to become aware of the ideas and concepts that make them capable of living as conscious citizens in the context of the challenges of capitalist globalization. In his view, "the formation of an environmental citizenship is a strategic component of the process of building democracy" (GADOTTI, 2008, p.31). After all, when we talk about sustainable life we understand it as a way of life of well-being and good living for all, in harmony (dynamic balance) with the environment: a fair, productive and sustainable way of life (GADOTTI, 2008, p .52). For the author, this implies educating for a culture of peace, social justice and sustainability.

The fight against environmental crimes is related to environmental education from two perspectives. The first is that the punishment for acts and damage to nature can be seen as educational for the individual and offending companies, especially for the fines imposed by the legislation. The second is related to failures and gaps in the formation of ecological awareness. Therefore, if environmental education has not been effective, punitive legal measures must be put in place to contain abusive acts at the individual and collective levels. It is a perspective that sees the arsenal of punitive devices as stimulators of moral reparation for offenders.

The punitive demand related to the natural environment emerged in the 1970s, due to the conception that the environment is not an abstraction, "because it represents the living space, the quality of life and the very health of human beings, including generations yet to come" (HAYEK, 1976, p.121). In that fork, the Stockholm Declaration, in 1972, established that the human being has the fundamental right to a quality environment. The concept that environmental crimes are attempted against the human species was also consecrated, since the deliberate destruction of habitat or access to food or drinking water "on a significant scale could represent an infringement of fundamental human rights” (FREELAND, 2005, p.135).

Among the environmental laws passed in the last decades, the informants highlight four of them: Law of the National System of Nature Conservation Units (SNUC), with 25.30\%; National Environmental Education Policy Law (15.94\%); Environmental Crimes Law (15.34\%); National Environmental Policy Law (11.45\%). Conservation units were conceived in the 1930s in Brazil, in response to the advance of industrialization and urbanization. They are anchored in a biocentric perspective, which represents nature as a common good to be conserved in its natural form, in order to maintain the functions of the ecosystem, in addition to ensuring the quality of human life (PEREIRA ET AL, 2017; BARROS, 2018 ).

The emphasis on the law that instituted the SNUC is certainly due to the per- 
ception of the informants regarding the importance of protected areas, one of the flags of most environmental entities and movements. There is also a relationship between the emphasis on environmental conservation and the two themes prioritized by the public's perception: climate change and combating deforestation. Environmentalists are consensual when stating that the increase in protected areas contributes to reducing the impacts of deforestation, one of the causes of the effects on the global climate (RYAN, 2017).

The emphasis on the Law on the National Environmental Education Policy and the Law on Environmental Crimes from the perspective of the informants also has a relation with the themes prioritized by the public's perception, based on the arguments already mentioned that environmental education is considered an important socialization factor for sustainability (CARVALHO, 2017). Punishment for damage to nature, however, is seen by respondents as a mechanism that should also not be discarded.

The National Environmental Policy Law is among the most important in the ranking, certainly due to the historical landmark it represents. Edited in the dictatorial period (1981), the law was considered innovative, as it contemplated "an instrument, in terms of public policies for the environment" (ARAÚJO, 2008, p.236). On the other hand, there are studies that show that Brazilian environmental policy developed "in a way that is late in relation to other sectoral policies and due to external pressures from developed countries and multilateral organizations, such as the UN" (BARROS, 2015, p .160). Pimentel, Novaes and Dias (2017, p.129) point out that it is surprising that the Law has not been updated until today, since several environmental themes have emerged since then. Its main contribution, however, in the view of the aforementioned authors, was to inaugurate an institutional policy trail for environmental policies. Despite the controversies in the literature, the fact is that the referred law was mentioned by the informants as one of the most important in the environmental area.

Regarding the predominance of the nature of the informants' perceptions, a brief comment on how they were and / or are constituted should be mentioned. For this, we used the evaluative repertoire of the informants themselves, based on open responses. In these terms, four factors stand out: professional experience in the environmental area; experience in following the ecological debate; the oscillations between advances and retreats of the Federal Government and the National Congress in relation to environmental policies and laws; the critical assessment of environmental entities and scientific institutions considered suitable by the respondents.

In the first two cases, the arguments support the fact that $78.8 \%$ of respondents work in the environmental area. Therefore, as one of the informants summarizes: "professional experience in the area leads us to follow the political debate on environmental issues in a more attentive and continuous manner, which shapes our most critical view". As for variations in the direction of environmental policies and laws, another report explains that "now we are encouraged by the positive measures and initiatives of the government and Congress, but from time to time we are also surprised by proposals that disappoint us, as in the case of revision of the Forest Code, a typical predominance of forces opposed to preservation". 
Finally, some statements emphasize the relevance of studies carried out by environmental entities and research institutions: "we clearly perceive that there is convergence between these studies, which all point in the same direction, which is the need for development policies that take into account the factor in all sectors of the economy ".

\section{Final comments}

Considering the issues examined in the article, the profile of the public that participates in public hearings promoted by CMADS draws attention. There is a predominance of men between 31 and 50 years of age, with higher education, monthly family income between 10 and 15 minimum wages, sympathizers or members of left and center political parties. It is also noteworthy that $78.80 \%$ work in the environmental area, especially in the public sector, that is, professional motivations are relevant to attend public hearings.

The profile data is directly connected with the main theoretical issues discussed in the first part of the text, especially those that call attention to the importance of the subjects' social perspective for the formation of social and environmental perceptions. In the case under study, the theoretical framework contributes to the understanding of such perspectives based on variables related to the profile of the informants: sex, education, income, professional activity and party sympathy. This profile is relevant to the understanding of the perceptions exposed above and how they were and are constituted.

Respondents' perceptions vary depending on the questions assessed. One aspect of the perceptions highlights the opening of CMADS to citizen participation, the agenda for discussions and the performance of exhibitors with high technical knowledge and links with the environmental sector. Another aspect highlights the lack of interest and lack of commitment of parliamentarians in debates, the use of debates to reinforce and legitimize the political positions of government agencies, in addition to aspects related to the dynamics of hearings: delay of parliamentarians, reduction of exposure time of guests due to delays, superficial debate and lack of disclosure of events.

Still according to the theoretical framework presented in the first part of the text, the individuals' daily experiences and experiences have a special relevance in the formation of social, political and environmental perceptions. In the case under study, the citizens' assessment of the political interference of parliamentarians linked to agribusiness interests in the environmental debates promoted by CMADS draws attention. In this sense, the so-called "Rural Bench" is pointed out by the informants as an actor who has boycotted the advance of environmental laws in Brazil. The changes in the Forest Code in 2012 are cited as examples of the power of the referred bench to favor the agro sector.

In short, the study confirms the theoretical assumptions presented at the beginning of the text about the relevance of empirical studies on socio-environmental perceptions for the understanding of specific aspects such as the improvement of environmental 
management policies that contemplate the collective interest. Furthermore, the justifications of the individuals surveyed can serve as feedback to the actors who promote and participate in the public audiences under examination.

\section{REFERENCES}

AGUILAR CUCURACHI, M. S.; MERÇON, J; SILVA, E. Aportaciones de las percepciones socioecológicas a la Educación Ambiental. Entreciencias, v.5, n.15, p.95-110, 2018.

ALLOUCHE, A.; NICOLAS, L. Entre perceptions, publicisation et stratégies d'acteurs. VertigO-la revue électronique en sciences de l'environnement, n.21, 2015.

ARAÚjO, S. M. V. Vinte e cinco anos da Lei da Política Nacional do Meio Ambiente. Plenarium, v.5, n.5, p.236-243, 2008.

BARDIN, L. Análise de conteúdo. Lisboa: Edições 70, 2005.

BARROS, A.T. O projeto de transparência do Senado Federal: entre a accountability e a propaganda política. Sociologias, v.17, n.39, p.338-368, 2015a.

BARROS, A.T. Sociologia da mídia: principais perspectivas e contrapontos. Século XXI - Revista de Ciências Sociais, v.5, p.186-222, 2015 b.

BARROS, A.T. A Esquerda Verde: Partidos Políticos e Ambientalismo Radical no Brasil. Dados, v.61, p.503-540, 2018.

BARROS, A. T.; MONTEIRO, A. R.; SANTOS, T. T. Audiências públicas interativas na Câmara dos Deputados. Revista Brasileira de Ciência Política, n.26, p. 131-185, 2018.

BIDERBOST, P. Percepciones políticas en contraste. VIII Congreso de la Asociación Española de la Ciencia Política y de la Administración, Valencia. 2007.

BONNEMAINS, A. Perceptions et représentations du changement climatique auprès des populations dans leur cadre de vie. Thèse de doctorat (Sciences de l'Homme et Société/Etudes de l'environnement). Laboratoire d'excellence Innovation et Territoires de Montagne. Université Grenoble Alpes, 2016.

BOY, E; BRUCE, N.; DELGADO, H. Birth weight and exposure to kitchen wood smoke during pregnancy in rural Guatemala. Environmental health perspectives, v.110, n.1, p.109-114, 2002.

CARVALHO, Isabel Cristina de Moura. Ecologia: um campo estratégico. Revista de Cultura Vozes. Petrópolis, v.84, n.2, p.234-241, mar./abr. 1990.

CARVALHO, Isabel Cristina de Moura; STEIL, Carlos Alberto. Percepção e ambiente: aportes para uma epistemologia ecológica. Revista Eletrônica Mestrado em Educação Ambiental. Volume especial, março, p.59-79, 2013

CARVALHO, Isabel Cristina de Moura. Educação ambiental: a formação do sujeito ecológico. 
Campinas: Cortez, 2017.

COVEYOU, M. R.; PIERESON, J. Ideological perceptions and political judgement: Some problems of concept and measurement. Political Methodology, p. 77-102, 1977.

CONOVER, P. J. The influence of group identifications on political perception and evaluation. The Journal of Politics, v. 46, n. 3, p. 760-785, 1984.

DURAND, L. De las percepciones a las perspectivas ambientales: una reflexión teórica sobre la antropología y la temática ambiental. Nueva antropología, v.21, n.68, p.75-87, 2008.

DOUGLAS, M. Cultural bias. Royal Anthropological Institute, 1978.

DOUGLAS, M.. Introduction. In: DOUGLAS, Mary (Org.) Essays on the Sociology of Perception. London: Routledge, 2013, p.1-9.

DUNLAP, R. E.; MERTIG, Angela G. Global environmental concern: An anomaly for postmaterialism. Social Science Quarterly, v. 78, n. 1, p. 24-29, 1997.

DUNLAP, R. E. Lay perceptions of global risk: Public views of global warming in cross-national context. International sociology, v.13, n.4, p.473-498, 1998.

ETCHEGARAY DONDÉ, L. Las percepciones y representaciones sociales: elementos claves para el análisis de la cultura política. In: Ponencia. Congreso Internacional XXIII de Latin American Studies Association. 2001.

EVELAND JR, W. P.; HUTCHENS, Myiah J. The role of conversation in developing accurate political perceptions. Human Communication Research, v.39, n.4, p.422-444, 2013.

FERNÁNDEZ, Y. M. i Por qué estudiar las percepciones ambientales? Espiral, v.15, n.43, p.179202, 2008.

GIBSON, J. J. The ecological approach to visual perception. Psychology Press, 1979.

GIDDENS, A. A constituição da sociedade. São Paulo: Martins Fontes, 2009.

GOULD, K. A. Pollution and perception: Social visibility and local environmental mobilization. Qualitative Sociology, v.16, n.2, p.157-178, 1993.

HOLZER, W. A geografia humanista: uma revisão. Espaço e cultura, Rio de Janeiro, n. 3, p. 8- 19, 1996.

JODELET, D. La representación social: fenómenos, concepto y teoria. In: MOSCOVICI, S. (ed.). Psicologia social. Paris: Press Universitaires de France, 1984, p.31-61.

LAHIRE, B. Homem plural. Lisboa: Instituto Piaget, 2003.

LEE, Terence. Psicologia e meio ambiente. Rio de Janeiro: Zahar, 1977.

LIMA, P G. da C.; ARAÚJO, S. M. V. G.; SERAPHIM, Ana Paula A. C. C. O papel do Poder 
Legislativo. In: Marília Steinberger. (Org.). Território, agentes-atores e políticas públicas espaciais. Brasília: Ler Editora, 2017, p.253-278.

MAILLEFERT, M.; MERLIN-BROGNIART, C. Les modes de perception de la biodiversité par les acteurs et la régulation des usages de l'environnement. Développement durable et territoires. v.7, n.1, 2016.

MARIN, Andreia Aparecida. Pesquisa em educação ambiental e percepção ambiental. Pesquisa em Educação Ambiental, v.3, n.1, p.203-222, 2008.

MARQUES, E. Leis gerais, explicações e mecanismos: para onde vão nossas análises? Revista Brasileira de Ciências Sociais, v.22, n.64, 2007.

MERLEAU-PONTY, M. Fenomenologia da percepção. São Paulo: Martins Fontes, 1999.

MESQUITA, Raúl; DUARTE, Fernanda. Dicionário de psicologia. Lisboa: Plátano, 1996.

MILTON, K. Loving nature: towards an ecology of emotion. Psychology Press, 2002.

MOSCOVICI, S. Representações sociais. Petrópolis: Vozes, 2003.

NÓBREGA, T. P. Corpo, percepção e conhecimento em Merleau-Ponty. Estudos de Psicologia, v.13, n.2, p.141-148, 2008.

PIMENTEL, L.; NOVAES, V. W.; DIAS, R. C. Os agentes-atores na consolidação da política ambiental. In: Marília Steinberger. (Org.). Território, agentes-atores e políticas públicas espaciais. Brasília: Ler Editora, 2017, p.129-153.

RANCIÈRE, J. A partilha do sensível. São Paulo: Editora, v.34, 2009.

RELPH, E. Place and placelessness. Pion, 1976.

RYAN, D. Politics and climate change. Ambiente $\&$ Sociedade, v.20, n.3, p.271-286, 2017.

SLIMAK, M. W.; DIETZ, Thomas. Personal values, beliefs, and ecological risk perception. Risk Analysis, v.26, n.6, p.1689-1705, 2006.

VALLE, M.; PERREWE, P. L. Do politics perceptions relate to political behaviors? Tests of an implicit assumption and expanded model. Human Relations, v.53, n.3, p.359-386, 2000.

TUAN, Yi-Fu. Topophilia: A study of environmental perceptions, attitudes, and values. Columbia University Press, 1972.

YEARLEY, S. The Green Case: A Sociology of Environmental Issues, Arguments and Politics. Routledge, 2014.

YOUNG, I. M. La justicia y la política de la diferencia. Universitat de València, 2000. 
Antonio Teixeira de Barros

$\square$ antonibarros@gmail.com

ORCiD: http://orcid.org/0000-0002-3061-8202
Submitted on: 15/05/2019

Accepted on: 03/07/2020

2021;24:e00832

How to cite: BARROS, A. T. de. Socio-political-environmental perceptions of participants in the public hearings of the Brazilian Representative House on Environment. Ambiente \& Sociedade. São Paulo, v. 24, p. 1-21, 2021. 


\title{
Percepções sociopolítico-ambientais dos participantes das audiências públicas da Câmara dos Deputados sobre Meio Ambiente
}

\author{
Antonio Teixeira de Barros
}

São Paulo. Vol. 24, 2021

Artigo Original
Resumo: $\mathrm{O}$ artigo analisa as percepções dos cidadãos que participaram das audiências públicas promovidas pela Comissão de Meio Ambiente e Desenvolvimento Sustentável (CMADS) da Câmara dos Deputados durante o ano de 2018. A metodologia consistiu no uso de questionário com perguntas abertas e fechadas aplicado a uma amostragem de $71,22 \%$ do público que esteve presente nesses eventos. Para o estudo das percepções, as questões abertas assumem especial relevância, visto que consistem em argumentos, análises e justificações apresentados pelos cidadãos. As conclusões mostram uma diversidade de percepções dos cidadãos em relação à agenda da CMADS, aos temas em debate e à participação de técnicos e representantes de entidades do campo ambiental. Por outro lado, há críticas à atuação dos parlamentares, dos representantes de órgãos governamentais e à dinâmica dos debates.

Palavras-chave: Percepções socioambientais; Audiências públicas; Comissão de Meio Ambiente e Desenvolvimento Sustentável; Câmara dos Deputados.

Como citar: BARROS, A. T. de. Percepções sociopolítico-ambientais dos participantes das audiências públicas da Câmara dos Deputados sobre Meio Ambiente. Ambiente \& Sociedade. São Paulo, v. 24, p. 1-21, 2021.

DOI: http://dx.doi.org/10.1590/1809-4422asoc20190083r2vu2021L1AO 


\title{
Percepções sociopolitico-ambientais dos participantes das audiências públicas da Câmara dos Deputados sobre Meio Ambiente
}

\author{
Antonio Teixeira de Barros
}

São Paulo. Vol. 24, 2021

Artículo original
Resumen: El artículo analiza las percepciones de los ciudadanos que participaron de las audiencias públicas promovidas por la Comisión de Medio Ambiente y Desarrollo Sostenible (CMADS) de la Cámara de Diputados durante el año 2018. La metodología consistió en el uso de cuestionario con preguntas abiertas y cerradas a un muestreo del $71,22 \%$ del público que estuvo presente en esos eventos. Para el estudio de las percepciones, las cuestiones abiertas asumen especial relevancia, ya que consisten en argumentos, análisis y justificaciones presentados por los ciudadanos. Las conclusiones muestran que existe uma diversidade de percepciones de los ciudadanos en relación a la agenda de la CMADS, a los temas en debate ya la participación de técnicos y representantes de entidades del campo ambiental. Por otro lado, hay criticas en relación a la actuación de los parlamentarios, de los representantes de órganos gubernamentales y la dinámica de los debates.

Palabras-clave: Percepciones ambientales; audiencias públicas; Comisión de Medio Ambiente y Desarrollo Sostenible; Camara de los Diputados.

Como citar: BARROS, A. T. de. Percepciones sociopolítico-ambientales de los participantes en las audiencias públicas de la Cámara de Diputados de Brasil sobre el Medio Ambiente. Ambiente $\mathbb{\&}$ Sociedade. São Paulo, v. 24, p. 1-21, 2021.

DOI: http://dx.doi.org/10.1590/1809-4422asoc20190083r2vu2021L1AO 